\title{
Benthic Polychaeta of the Middle Atlantic Bight: feeding and distribution
}

\author{
Gary R. Gaston \\ Department of Biological and Environmental Sciences, McNeese State University, Lake Charles, Louisiana 70609, USA
}

\begin{abstract}
Data on feeding biology was used to investigate distribution patterns of benthic polychaetes of the Middle Atlantic Bight off the United States East Coast. Feeding biology classifications used in the analyses were based on (1) gut-contents analyses of polychaetes collected in the study area; and (2) recent publications regarding polychaete feeding. Proportion of carnivorous polychaetes was greatest in coarser sediments, and decreased significantly with water depth across the continental shelf. Surface-deposit feeders numerically dominated most habitats. Abundance of surface-deposit feeders decreased across the continental shelf and sharply increased at the shelf break, paralleling the pattern of water-column production. Proportion of subsurface-deposit feeders was greatest in finesediment habitats, and increased significantly with depth and percent organic carbon across the continental shelf. Sessile polychaetes generally inhabited physically stable habitats. Proportion of sessile polychaetes was positively correlated with percent silt and clay and percent organic carbon. Feeding and motility categories were generally more useful in distinguishing habitats than were morphology categories. Apparently, distribution and abundance of surface-deposit feeders were regulated by food resources from water-column production, and distribution of sessile polychaetes was limited primarily by physical disturbance.
\end{abstract}

\section{INTRODUCTION}

Recent interest has centered around shifts in dominance of invertebrate feeding groups between habitats (e.g. Rhoads 1974, Jumars \& Fauchald 1977, Woodin 1978, Fauchald \& Jumars 1979, Maurer \& Leathem 1981, Whitlatch 1981, Maurer et al. 1982). These studies used feeding biology data gathered over the past 100 yr. Because data on some invertebrate groups were lacking, many of the feeding classifications used were based on speculation rather than observation. Although polychaetes were often the numerically dominant invertebrate group in these studies, polychaete feeding classifications were generally supported by the least data. In their summary of the feeding biology of polychaetes, Fauchald \& Jumars (1979) emphasized the need for more extensive polychaete feeding data. Their observations led to this study.

The purpose of this investigation was to study the feeding biology of Middle Atlantic benthic polychaetes using gut-contents analyses of polychaetes collected in the Middle Atlantic Bight, off the USA East Coast. This information was then used to characterize cross-shelf habitats by dominance of feeding groups. I examined distributions of several polychaete feeding biology categories, and these results led to generalized distribution patterns for polychaetes.

Animal-sediment relationships in widely variant habitats can be explored by hypotheses based on abundance of macrofaunal feeding groups. I proposed that the proportion of the 3 detritivore feeding groups (suspension feeders, surface-deposit feeders, and subsurface-deposit feeders) varied among habitats. To test this, the relative proportion of each feeding group was compared among various habitats of the continental shelf and slope, with each habitat distinguished by environmental parameters (e.g. sediment grain size, organic carbon). I also examined the possibility that sessile polychaetes were more abundant in deeper water and in finer sediments. Jumars \& Fauchald (1977) showed a positive correlation between water depth and proportion of sessile polychaetes off Southem California. They postulated that the correlation was actually due to increased sediment stability with water depth. To test this, data collected in outer-shelf ridge fields of the Middle Atlantic Bight (described by Swift et al. 1973) were used here to compare sediment texture with abundance of organisms in the feeding groups. Thus, proportion of sessile polychaetes was 
compared among habitats of comparable depth, but variable sediment stability.

\section{MATERLALS AND METHODS}

Specimens for this study were collected during the Bureau of Land Management (BLM) Middle Atlantic Bight study of the mid-1970's (Boesch 1979a, b). All polychaete species collected were classified by feeding biology. Feeding data were based on gut-contents analyses, and where conclusive data on feeding were available, on available literature. Many of the gutcontents analyses led to changes in classifications from those hypothesized by Fauchald \& Jumars (1979). For instance, I classified spionids as both surface-deposit feeders and suspension feeders as Maurer \& Leathem (1981) had done, since recent studies (e.g. Levin 1980, Taghon et al. 1980, Dauer et al. 1981, Daúer 1983) indicated that spionids may feed either way. The total number of spionid individuals collected at each site was divided equally between the 2 feeding categories.

Generally, only complete specimens were dissected for gut-contents analyses. Incomplete specimens were used only when complete specimens were not available (i.e. rare species). All specimens were dissected under stereomicroscopy. Large specimens were opened with iris scissors and the digestive tract was removed and opened with a microknife. Small specimens were mounted whole on a slide and the ingested material was squeezed on to a slide with a fine probe. A record was made of any material found in the pharynx, esophagus, or intestine. Material removed from the gut was then viewed under compound microscopy, and (where necessary) scanning electron microscopy (AMRAY 1000 SEM).

Feeding classifications were assigned based on observations of material removed from the specimens' digestive tracts. Specimens with only detritus in their guts were classified as deposit feeders. Specimens which ingested other organisms were called carnivores. Guts of many suspected carnivores were empty. Thus, for several species (e.g. Aglaophamus circinata, Lumbrinerides acuta, Goniadella gracilis) it was necessary to dissect over 50 specimens before any ingested material was observed. Specimens which ingested only plant matter such as algal filaments or diatoms were classified as herbivores.

Feeding categories for all species were based on the 3 feeding biology criteria originally proposed by Jumars \& Fauchald (1977): polychaete feeding mode; feeding motility; and feeding morphology. Feeding mode included 5 components: (1) surface-deposit feeder; (2) subsurface-deposit feeder; (3) suspension feeder; (4) carnivore; and (5) herbivore. Motility included 3 components: (1) motile; (2) discretely motile; and (3) sessile. 'Discretely motile' means that the organism was capable of moving from place to place, but was sessile when feeding. Functional feeding morphology included: (1) jawed; (2) tentaculate; (3) pumping; and (4) soft proboscis.

Ternary diagrams were used to characterize sites (= stations) by feeding biology criteria. Ternary diagrams are based on percentage of 3 component groups. The total of the 3 components equals $100 \%$. When used for comparisons of primary sediments (sand, silt, and clay) collected from several sites, the proportion of each sediment component is plotted as a point on the diagram (each point represents a site). Thus, it is possible to compare sediments of many sites on a single diagram, as is common practice in geology. In this study, the 3 feeding biology criteria (feeding, motility, and morphology) were each used for site characterization. Sites of the study were classificd by 3 components of detritivores (surface-deposit feeders, subsurfacedeposit feeders, and suspension feeders), 3 compo-

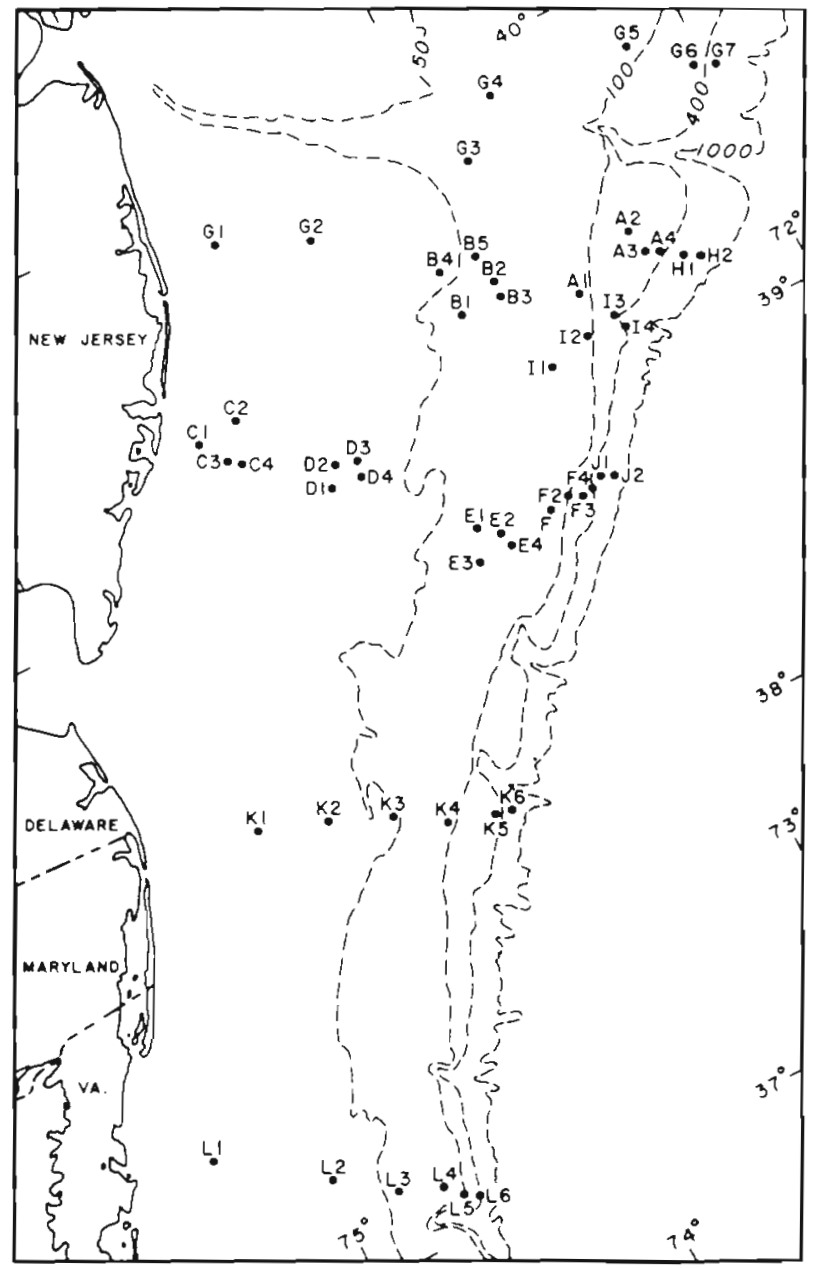

Fig. 1. Location of collection sites in the Middle Atlantic Bight, USA. Depth indicated in meters. From Boesch (1979a) 
Table 1. Sampling schedule and replication of grab samples taken for polychaetes in the Middle Atlantic Bight, USA

\begin{tabular}{|c|c|c|c|c|c|c|c|c|}
\hline \multirow[t]{4}{*}{ Station } & \multicolumn{8}{|c|}{ Number of replicates } \\
\hline & \multicolumn{5}{|c|}{ Year 1} & \multirow{2}{*}{\multicolumn{3}{|c|}{$\begin{array}{c}\text { Year } 2 \\
1977\end{array}$}} \\
\hline & \multirow{2}{*}{$\begin{array}{c}1975 \\
\text { Fall }\end{array}$} & \multicolumn{4}{|c|}{1976} & & & \\
\hline & & Winter & Spring & Summer & Fall & Winter & Spring & Summer \\
\hline $\mathrm{A} 1-4, \mathrm{~B} 1-4, \mathrm{C} 2, \mathrm{C} 4, \mathrm{D} 1, \mathrm{D} 4, \mathrm{E} 1-4, \mathrm{~F} 1-4$ & 6 & 6 & 6 & 6 & 6 & 6 & 6 & 6 \\
\hline $\mathrm{C} 1, \mathrm{C} 3, \mathrm{D} 2, \mathrm{D} 3$ & 6 & 6 & 6 & 6 & & & & \\
\hline B5 & & & & & 6 & 6 & 6 & 6 \\
\hline G2-6, I1-3, K2, K4-6, L2, L4-6 & & 6 & & 6 & & 4 & & 4 \\
\hline $\mathrm{H} 1-2, \mathrm{I} 4, \mathrm{~J} 1-2$ & & 6 & & 6 & & 6 & & 6 \\
\hline $\mathrm{G} 1, \mathrm{~K} 1, \mathrm{~K} 3, \mathrm{~L} 1, \mathrm{~L} 3$ & & 6 & & 6 & & & & \\
\hline G7 & & 1 & & 6 & & & & \\
\hline
\end{tabular}

nents of motility (motile species, discretely motile species, and sessile species), and 3 components of morphology (tentaculate species, jawed species, and soft-proboscis species). Information for classification of all species was based on Fauchald \& Jumars (1979) supplemented with observations provided in this study (from Gaston 1983).

During the 2 yr BLM Middle Atlantic Bight study, a total of 52 stations were repetitively sampled (Fig. 1). Table 1 lists these stations, and indicates the number of replicates collected and time of collection. All samples of macrobenthos were collected with a $0.1 \mathrm{~m}^{2}$ stainless steel Smith-McIntyre grab.

Once onboard ship each sample was washed with seawater in order to float light-bodied organisms out of the sample. These specimens were collected on a $0.5 \mathrm{~mm}$ mesh Nitex screen below the bucket. The screen was removed when rinsing was completed, placed in a labelled cloth bag, anesthetized in isotonic $\mathrm{MgCl}_{2}$, and specimens were killed and fixed with $10 \%$ buffered formalin with Rose Bengal as a stain. The sediments and heavy organisms which remained in the bucket were washed on a $0.5 \mathrm{~mm}$ mesh screen sieve, treated as above, and removed from the sediment in the laboratory.

Statistical analyses in this investigation included determination of product-moment correlation coefficients for polychaete feeding biology components and sediment parameters (Sokal \& Rohlf 1981). Correlation coefficients were calculated for number of individuals of each feeding biology criterion in a given depth zone versus mean sediment diameter (phi units), and percentage of sand, silt, clay, and organic carbon. Correlation coefficients were calculated on both the crossshelf data set (all stations, all collections), and the ridge field subset of stations (ridge field stations only, for tests of medium-scale distribution patterns).

The spatial patterns here defined as 'medium scale' and 'broad scale' refer to cross-shelf distributions on a scale of hundreds to thousands of meters and tens of thousands of meters, respectively. Habitat zones of the
Middle Atlantic Bight were divided into 5 habitat groups for analyses of broad scale patterns in polychaete feeding biology: inner shelf; middle shelf; outer shelf; shelf break; and slope. The broad-scale zone divisions were based primarily on relative depth. Medium-scale analyses concerned habitats within areas of ridge and swale topography on the outer shelf.

\section{RESULTS}

Gut contents analyses were conducted on all polychaete species collected from the Middle Atlantic Bight for which there were not previous feeding biology data or for which data were inconclusive or contradictory. This included 64 taxa (Table 2). A summary of available literature on feeding of polychaetes was provided by Fauchald \& Jumars (1979). Results of the present investigation are compared to classifications by Fauchald \& Jumars in Table 2.

Many of the specimens of carnivorous polychaetes (e.g. aphroditids, arabellids, dorvilleids, glycerids, goniadids) dissected for this study had empty guts (Table 2). Many previous investigators also noted this, and attributed absence of food in the gut to the nature of a predatory life (reviewed by Fauchald \& Jumars 1979).

There were conflicting feeding modes reported in the literature for many of the species dissected for this investigation (Table 2). Arabellids, dorvilleids, glycerids, lumbrinerids, and nephtyids were variously reported to be either deposit feeders or carnivores. Data in this study indicated that all of the arabellids, glycerids, nephtyids, and some dorvilleids and lumbrinerids were carnivores in the Middle Atlantic Bight. Some of the small dorvilleid species (Schistomeringos spp.) and juvenile and small species of some lumbrinerids (Lumbrineris fragilis, L. impatiens, L. latreilli, and Ninoe nigripes) were deposit feeders.

There was little or no information on feeding of some of the most commonly collected species of polychaetes in the Middle Atlantic Bight (e.g. eunicids, some lum- 
Table 2. Results of polychaete gut contents analyses and feeding classifications of this study compared to the feeding biology classifications available in previous literature (summarized by Fauchald \& Jumars 1979). Classifications: surface-deposit feeder (S); subsurface-deposit feeder $(B)$; suspension feeder $(F)$; carnivore $(C)$; herbivore $(H)$; motile $(M)$; discretely motile (D); sessile $(\mathrm{L})$; tentaculate $(\mathrm{T})$; jawed $(\mathrm{J})$; pumping $(\mathrm{P})$; and soft proboscis $(\mathrm{X})$

\begin{tabular}{|c|c|c|c|c|}
\hline Species & $\begin{array}{l}\text { Number } \\
\text { dissected }\end{array}$ & $\begin{array}{l}\text { Ingested material } \\
\text { (No. of specimens) }\end{array}$ & $\begin{array}{l}\text { Present } \\
\text { classification }\end{array}$ & $\begin{array}{l}\text { Previous } \\
\text { classification }\end{array}$ \\
\hline \multicolumn{5}{|l|}{ Ampharetidae: } \\
\hline Ampharete arctica & 3 & Detritus (3) & SLT & SLT \\
\hline Anobothrus gracilis & 14 & Detritus (14) & SLT & SLT \\
\hline Auchenoplax crinita & 5 & Detritus (5) & SLT & SLT \\
\hline Melinna cristata & 3 & Detritus (3) & SLT & SLT \\
\hline \multicolumn{5}{|l|}{ Amphinomidae: } \\
\hline Paramphinome jeffreysii & 26 & Empty (26) & $\mathrm{CMX}$ & $\mathrm{CMX}$ \\
\hline \multicolumn{5}{|l|}{ Aphroditidae: } \\
\hline Aphrodita hastata & 25 & $\begin{array}{l}\text { Empty }(18) ; \text { coarse sand }(4) \\
\text { polychaetes }(3)\end{array}$ & CMJ & $\mathrm{CMJ}$ \\
\hline Laetmonice filicornis & 2 & Empty (2) & $\mathrm{CMJ}$ & $\mathrm{CMJ}$ \\
\hline \multicolumn{5}{|l|}{ Arabellidae: } \\
\hline Arabella mutans & 5 & Empty (5) & $\mathrm{CMJ}$ & CMJ, SMJ \\
\hline Drilonereis longa & 19 & Empty (13); forams (6) & $\mathrm{CMJ}$ & CMJ, SMJ \\
\hline Drilonereis magna & 11 & Empty $(10) ;$ peracarids (1) & $\mathrm{CMJ}$ & $\mathrm{CMJ}, \mathrm{SMJ}$ \\
\hline \multicolumn{5}{|l|}{ Capitellidae: } \\
\hline Mediomastus californiensis & 15 & Detritus (15) & BMX & $\mathrm{BMX}(?)$ \\
\hline Notomastus latericeus & 15 & Detritus (15) & $\mathrm{BMX}$ & $\mathrm{BMX}$ \\
\hline \multicolumn{5}{|l|}{ Dorvilleidae: } \\
\hline Protodorvillea minuta & 29 & Empty (28); forams (1) & $\mathrm{CMJ}$ & $\mathrm{HMJ}, \mathrm{CMJ}, \mathrm{SMJ}$ \\
\hline Protodorvillea gaspeensis & 5 & Empty (5); & $\mathrm{CMJ}$ & $\mathrm{HMJ}, \mathrm{CMJ}, \mathrm{SMJ}$ \\
\hline Protodorvillea kefersteini & 12 & Empty (11); peracarid (1) & $\mathrm{CMJ}$ & $\mathrm{HMJ}, \mathrm{CMJ}, \mathrm{SMJ}$ \\
\hline Schistomeringos caeca & 17 & Detritus (16); detritus and foram (1) & SMJ & HMJ, CMJ, SMJ \\
\hline \multicolumn{5}{|l|}{ Eunicidae: } \\
\hline Eunice antennata & 2 & Detritus (2) & $\mathrm{BDJ}$ & CDJ (?) \\
\hline Eunice pennata & 4 & Detritus (4) & $\mathrm{BDJ}$ & CDJ (?) \\
\hline Eunice vittata & 21 & Detritus (21) & BDJ & CDJ (?) \\
\hline Marphysa bellii & 13 & Detritus (13) & $\mathrm{BDJ}$ & $?$ \\
\hline \multicolumn{5}{|l|}{ Fauveliopsidae: } \\
\hline Fauveliopsis sp. A & 8 & Detritus (8) & SLX & $\mathrm{BMX}, \mathrm{BLX}$ \\
\hline \multicolumn{5}{|l|}{ Glyceridae: } \\
\hline Glycera capitata & 15 & Empty $(15)$ & CDJ & CDJ, BMJ (?) \\
\hline Glycera dibranchiata & 29 & $\begin{array}{l}\text { Empty (22); coarse sand (5); amphipod (1); } \\
\text { polychaete (1) }\end{array}$ & CDJ & $\mathrm{CDJ}, \mathrm{BMJ}(?)$ \\
\hline Glycera robusta & 6 & Empty $(6)$ & $\mathrm{CDJ}$ & $\mathrm{CDJ}, \mathrm{BMJ}(?)$ \\
\hline Hemipodus roseus & 5 & Empty $(4) ;$ coarse sand (1) & CDJ & $\mathrm{CDJ}, \mathrm{BMJ}(?)$ \\
\hline \multicolumn{5}{|l|}{ Goniadidae: } \\
\hline Goniada brunnea & 18 & Empty $(17) ;$ peracarid (1) & CDJ & $\mathrm{CDJ}$ \\
\hline Goniada maculata & 4 & Empty (4) & $\mathrm{CDJ}$ & CDJ \\
\hline Goniada norvegica & 2 & Empty (2) & $\mathrm{CDJ}$ & CDJ \\
\hline Goniada teres & 2 & Empty (2) & CDJ & $\mathrm{CDJ}$ \\
\hline Goniadella gracilis & 114 & $\begin{array}{l}\text { Empty (99); undigested food (12); } \\
\text { polychaetes and forams (3) }\end{array}$ & $\mathrm{CMJ}$ & CDJ \\
\hline \multicolumn{5}{|l|}{ Hesionidae: } \\
\hline Gyptis sp. A & 8 & Empty (8) & $\mathrm{CMJ}$ & CMJ (?) \\
\hline \multicolumn{5}{|l|}{ Lumbrineridae: } \\
\hline Lumbrinerides acuta & 103 & $\begin{array}{l}\text { Empty (92); undigested food (2); coarse } \\
\text { sand (2); forams (7) }\end{array}$ & $\mathrm{CMJ}$ & $?$ \\
\hline Lumbrineris albidentata & 8 & Empty $(6) ;$ coarse sand (2) & $\mathrm{CMJ}$ & $?$ \\
\hline Lumbrineris fragilis & 40 (15 juv) & Empty (25): detritus (15 juv) & CMJ, BMJ (juv) & $\mathrm{CMJ}$ \\
\hline Lumbrineris impatiens & $62(30$ juv $)$ & Empty (12): detritus $(20+30$ juv $)$ & $\mathrm{BMJ}$ & $\mathrm{BMJ}(?)$ \\
\hline Lumbrineris latreilli & $20(10$ juv $)$ & Detritus (20) & $\mathrm{BMJ}$ & $?$ \\
\hline Ninoe nigripes & 48 (21 juv) & Detritus (48) & $\mathrm{BMJ}$ & $B M J$ \\
\hline
\end{tabular}


Table 2 (continued)

\begin{tabular}{|c|c|c|c|c|}
\hline Species & $\begin{array}{l}\text { Number } \\
\text { dissected }\end{array}$ & $\begin{array}{l}\text { Ingested material } \\
\text { (No. of specimens) }\end{array}$ & $\begin{array}{l}\text { Present } \\
\text { classification }\end{array}$ & $\begin{array}{l}\text { Previous } \\
\text { classification }\end{array}$ \\
\hline \multicolumn{5}{|l|}{ Maldanidae: } \\
\hline Praxillura longissima & 3 & Detritus (3) & SLX & BLX \\
\hline \multicolumn{5}{|l|}{ Nephtyidae: } \\
\hline Aglaophamus circinata & 50 & $\begin{array}{l}\text { Empty }(44) ; \text { coarse sand (2); forams (2); } \\
\text { polychaetes (2) }\end{array}$ & $\mathrm{CMJ}$ & $\mathrm{CMJ}$ \\
\hline Nephtys bucera & 27 & $\begin{array}{l}\text { Empty (24); coarse sand and peracarids (1); } \\
\text { polychaete setae (2) }\end{array}$ & $\mathrm{CMJ}$ & $\mathrm{CMJ}$ \\
\hline Nephtys incisa & 4 & Empty (4) & CMJ & $\mathrm{CMJ}, \mathrm{BMJ}(?)$ \\
\hline Nephtys picta & 5 & Empty (5) & $\mathrm{CMJ}$ & $\mathrm{CMJ}$ \\
\hline Nephtyidae (juv) & 40 & $\begin{array}{l}\text { Empty }(36) ; \text { undigested food (1); undi- } \\
\text { gested tood and polychaete setae (3) }\end{array}$ & $\mathrm{CMJ}$ & $\mathrm{CMJ}$ \\
\hline \multicolumn{5}{|l|}{ Nereididae: } \\
\hline Ceratocephale loveni & 20 & Detritus (7); detritus and forams (13) & SDJ & $?$ \\
\hline Nereis grayi & 49 & $\begin{array}{l}\text { Empty (5); detritus }(40) ; \text { detritus and } \\
\text { fecal pellets (4) }\end{array}$ & SDJ & $?$ \\
\hline Nereis zonata & 21 & Empty $(8) ;$ detritus $(13)$ & SDJ & SDJ \\
\hline \multicolumn{5}{|l|}{ Onuphidae: } \\
\hline Hyalinoecia artifex & 6 & Forams (1); peracarids (5) & $\mathrm{CMJ}$ & $\mathrm{CMJ}$ \\
\hline Nothria conchylega & 14 & Detritus (11); detritus and forams (3) & SMJ & $?$ \\
\hline Onuphis atlanticum & 6 & Detritus (6) & SDJ & $?$ \\
\hline Onuphis pallidula & 54 & Empty (5); detritus (49) & SDJ & $?$ \\
\hline \multicolumn{5}{|l|}{ Paraonidae: } \\
\hline Aricidea catherinae & 13 & Detritus (13) & SMX & SMX \\
\hline Aricidea cerrutii & 10 & Detritus (10) & SMX & SMX \\
\hline Aricidea simplex & 5 & Detritus (5) & SMX & SMX \\
\hline Aricidea wassi & 5 & Detritus (5) & $\mathrm{SMX}$ & SMX \\
\hline Cirrophorus lyriformis & 5 & Detritus (5) & $\mathrm{SMX}$ & SMX \\
\hline Levinsenia gracilis & 5 & Detritus (5) & SMX & SMX \\
\hline Paradoneis lyra & 5 & Detritus (5) & SMX & SMX \\
\hline \multicolumn{5}{|l|}{ Phyllodocidae: } \\
\hline Anaitides mucosa & 21 & Empty (21) & CMX & $\mathrm{CMX}$ \\
\hline Eteone sp. A & 10 & Empty (10) & CMX & CMX \\
\hline \multicolumn{5}{|l|}{ Sphaerodoridae: } \\
\hline Sphaerodoridium claparedii & 24 & Empty (20); detritus (4) & $\mathrm{SMX}$ & $\mathrm{BMX}$ \\
\hline \multicolumn{5}{|l|}{ Syllidae: } \\
\hline Exogone hebes & 57 & Empty (54); undigested food (3) & $\mathrm{HMJ}, \mathrm{CMJ}$ & $\mathrm{HMJ}, \mathrm{CMJ}$ \\
\hline Exogone verugera & 36 & Empty (23); undigested food (13) & $\mathrm{HMJ}, \mathrm{CMJ}$ & $\mathrm{HMJ}, \mathrm{CMJ}$ \\
\hline Sphaerosyllis eninaceus & 23 & Empty (19); undigested food (4) & $\mathrm{HMJ}, \mathrm{CMJ}$ & $\mathrm{HMJ}, \mathrm{CMJ}$ \\
\hline Typosyllis tegulum & 13 & Empty (8); undigested food and forams (5) & $\mathrm{CMJ}, \mathrm{SMJ}$ & $\mathrm{HMJ}, \mathrm{CMJ}$ \\
\hline
\end{tabular}

brinerids, some nereidids, onuphids). The eunicids and nereidids were all determined to be deposit feeders. Among the lumbrinerids, Lumbrinerides acuta and Lumbrineris albidentata were determined to be carnivores, as was the onuphid, Hyalinoecia artifex. The onuphids Nothria conchylega, Onuphis atlanticum and O. pallidula were all deposit feeders.

All polychaetes were then assigned to feeding groups. Data on distribution of feeding groups were reviewed for correlations of feeding groups with several variables. A positive correlation existed between carnivorous polychaetes and coarse sediments of the Middle Atlantic Bight. Carnivores were positively cor- related ( $r=0.926, \alpha \leq 0.01$ ) with coarse sand in ridge fields of the outer shelf. There was a negative correlation ( $\mathrm{r}=-0.970, \alpha \leq 0.05$ ) between percentage of carnivorous polychaetes and increasing depth across the shelf. Carnivorous polychaetes were also negatively correlated ( $r=-0.757, \alpha \leq 0.05$ ) with organic carbon from the inner shelf to the slope. The most numerically dominant carnivores were Goniadella gracilis and Lumbrinerides acuta, both jawed species. These species occurred at all depth zones on the continental shelf, but most densely populated coarse-sediment habitats.

Because the sediments of the study area varied 
greatly from New Jersey to Virginia, I examined each transect (Transects $G, K$ and L; Fig. 1) separately. In Transect $\mathrm{G}$, carnivorous polychaetes were negatively correlated with organic carbon $(\mathrm{r}=-0.788, \alpha \leq 0.05)$, percent silt and clay $(\mathrm{r}=-0.791, \alpha \leq 0.05)$, and median diameter of sediments $(\mathrm{r}=-0.828, \alpha \leq 0.05)$ from the inner shelf to the slope (Fig. 1). Along Transect $\mathrm{K}$ there was a negative correlation $(\mathrm{r}=-0.920, \alpha$ $\leq 0.01$ ) between carnivorous polychaetes and organic carbon. In Transect $L$ none of the above parameters were significantly correlated with the proportion of carnivorous polychaetes. These differences between transects were expected. Generally the northern areas of the Middle Atlantic Bight graded from coarse to fine sediments with depth, whereas the inner and middle shelf surficial sand (upper $20 \mathrm{~cm}$ ) off Virginia was primarily fine or very fine sand. On the outer shelf the sediments of Transect $L$ were coarser than inner shelf sediments. As a resuit, the polychaetes which dominated the sediments of the different areas varied dramatically.

Because so many of the Middle Atlantic Bight polychaetes were detritivores, I divided that group into 3 components according to classifications of Fauchald \& Jumars (1979): suspension feeders, surface-deposit feeders, and subsurface-deposit feeders. There was a significant negative correlation between abundance of surface-deposit feeders and increasing depth across the shelf $(r=-0.944, \alpha \leq 0.05)$, an increase-in abundance of surface-deposit feeders at the shelf break, and a slight decrease in their abundance down the slope. Surface-deposit feeders were negatively correlated with organic carbon $(r=-0.858, \alpha \leq 0.05)$ and percent fine sand $(r=-0.853, \alpha \leq 0.05)$ in the outer shelf ridge fields. The most abundant surface-deposit feeders were those species with feeding tentacles or palps (e.g. Tharyx spp., Caulleriella spp., Polycirrus spp., Spiophanes spp.) and some species of Paraonidae (Aricidea spp.). Proportion of subsurface-deposit feeders increased significantly with depth across the shelf $(r=0.982, \alpha \leq 0.01)$, decreased at the break, then increased again down the slope. They were positively correlated $(r=0.850, \alpha \leq 0.05)$ with organic carbon content in ridge fields. Subsurface-deposit feeders were best represented by active burrowers (e.g. some Lumbrineris spp., Scalibregma inflatum) and some species of maldanids. Suspension feeders were in greatest relative abundance at intermediate shelf depths, and were very poorly represented on the inner shelf and middle slope. Species of sabellids (especially Chone spp. and Euchone spp.) and spionids contributed most of the individuals of suspension feeders on the continental shelf.

Motile polychaetes numerically dominated all depth zones (Fig. 2). Sessile polychaetes were positively correlated with both organic carbon $(r=0.999, \alpha \leq 0.05$ )
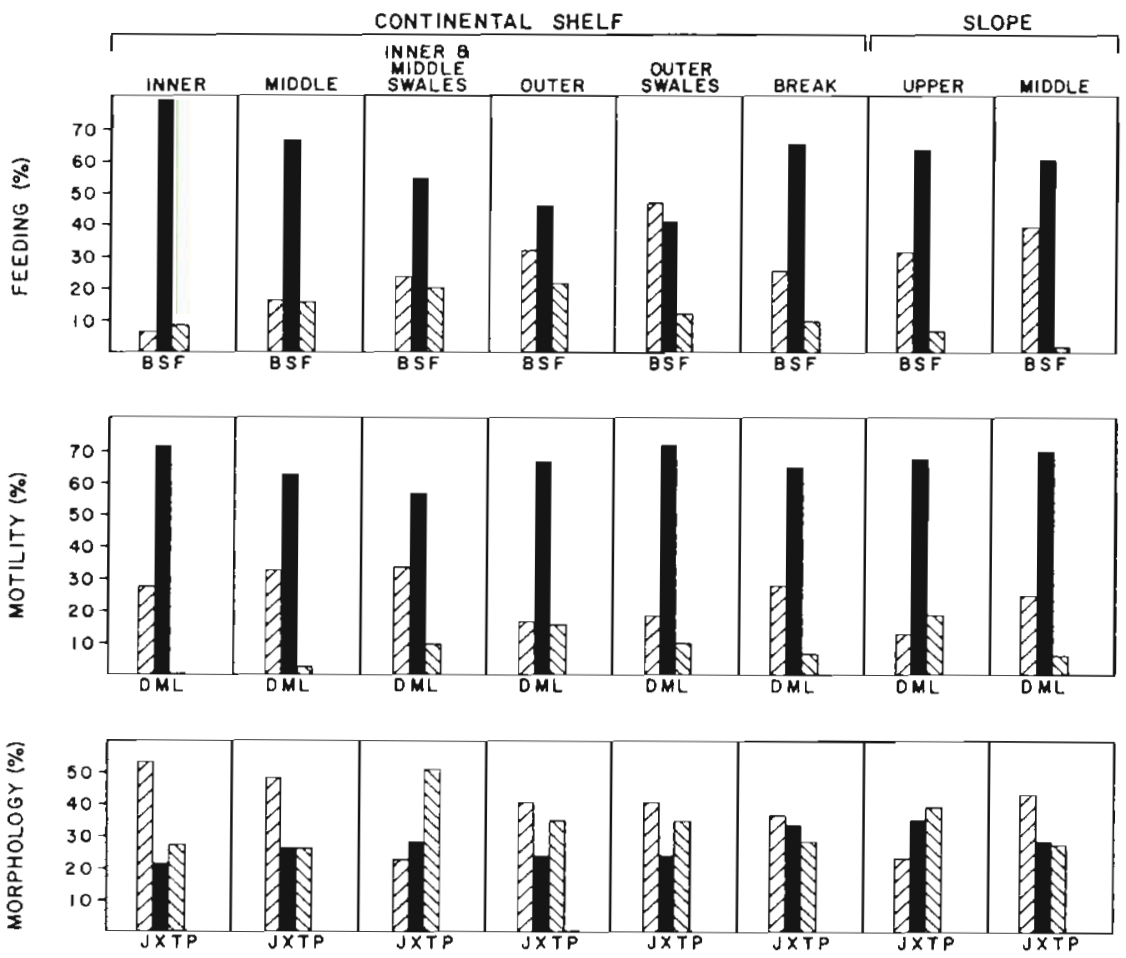

Fig. 2. Percentage of polychaete individuals in feeding, motility, and morphology categories by habitat. Categories: subsurfacedeposit feeders (B); surface-deposit feeders (S); suspension feeders $(F)$; discretely motile species (D); motile species (M); sessile species (L); jawed species (J); soft proboscis species $(\mathrm{X})_{i}$ tentaculate species $(T)$; and pumping species 
and percent silt and clay ( $\mathrm{r}=0.998, \alpha \leq 0.05)$ in nonswale habitats on the shelf. The relative proportion of sessile polychaetes was greatest at the upper slope $(19 \%)$, and was lowest on the inner shelf (less than $1 \%)$. The proportion of discretely motile polychaetes was greatest on the inner $(28 \%)$ and middle shelf $(33 \%)$ and at the shelf break $(28 \%)$.

Morphological components (Fig. 2) provided fewer consistent patterns with which to separate habitats than did other components. Jawed polychaetes were in greatest proportion at non-swale habitats of the inner $(53 \%)$ and middle shelf $(48 \%)$, and were in considerably smaller proportion $(23 \%)$ at inner and middle shelf swales (topographic lows). Tentaculate polychaetes were abundant in all zones, but in greatest proportion in the inner and middle shelf swales (51\%). Only a single species, Spiochaetopterus oculatus, was included in the class 'pumping'. This species was not abundant in the Middle Atlantic Bight. It contributed less than $1 \%$ of the polychaetes and was excluded from subsequent analyses.
Ternary diagrams (Fig. 3 to 5) were used to provide a model for characterizing each station by feeding, motility, and morphology classifications. Fig. 3 is a comparison of the 3 components of detritivores. Nonswale inner shelf habitats were dominated by surfacedeposit feeders, which provided over $95 \%$ of the individuals at some stations (e.g. Stns C2, C3). Middle shelf sites, with the exception of Stn L2, were dominated by surface-deposit feeders. Stn L2 supported many subsurface-deposit feeders, primarily lumbrinerids. Swale stations of the inner and middle shelf were different from other inner and middle shelf stations in abundance of feeding groups: these stations had a greater proportion of subsurface-deposit feeders, and in that regard more closely resembled outer shelf stations. Shelf break stations generally supported a lower proportion of subsurface-deposit feeders. There was an increase in proportion of suspension feeders from inner to outer shelf habitats, then a decrease in proportion of suspension feeders at the shelf break. Slope stations were distinguished in generally having

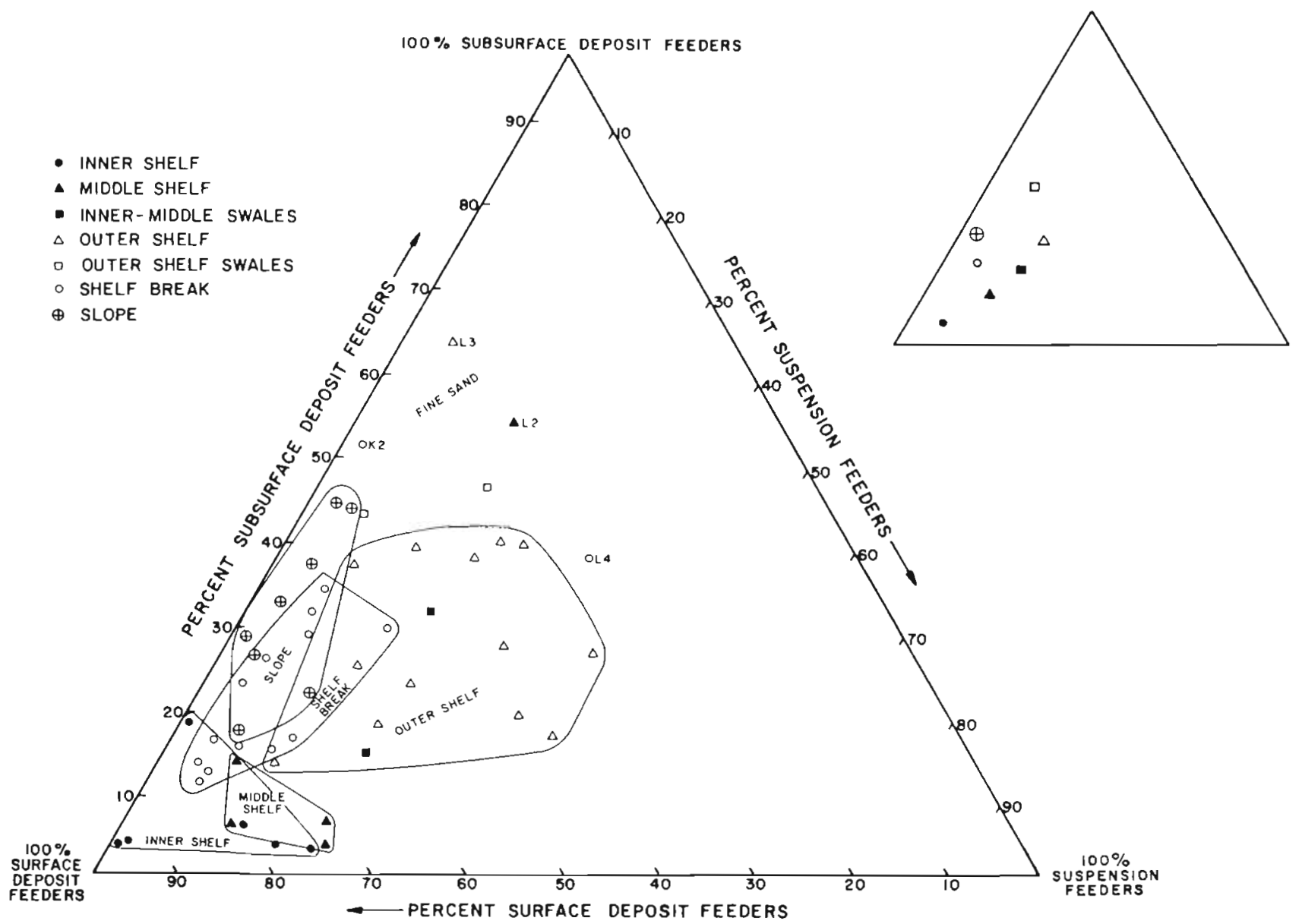

Fig. 3. Ternary diagram of broad scale sampling sites identified by habitat. Sites are distributed by percentage of the 3 components of deposit-feeding polychaetes: surface, subsurface, and suspension. Mean values of sites in each habitat are plotted as centroids in the small diagram at right 


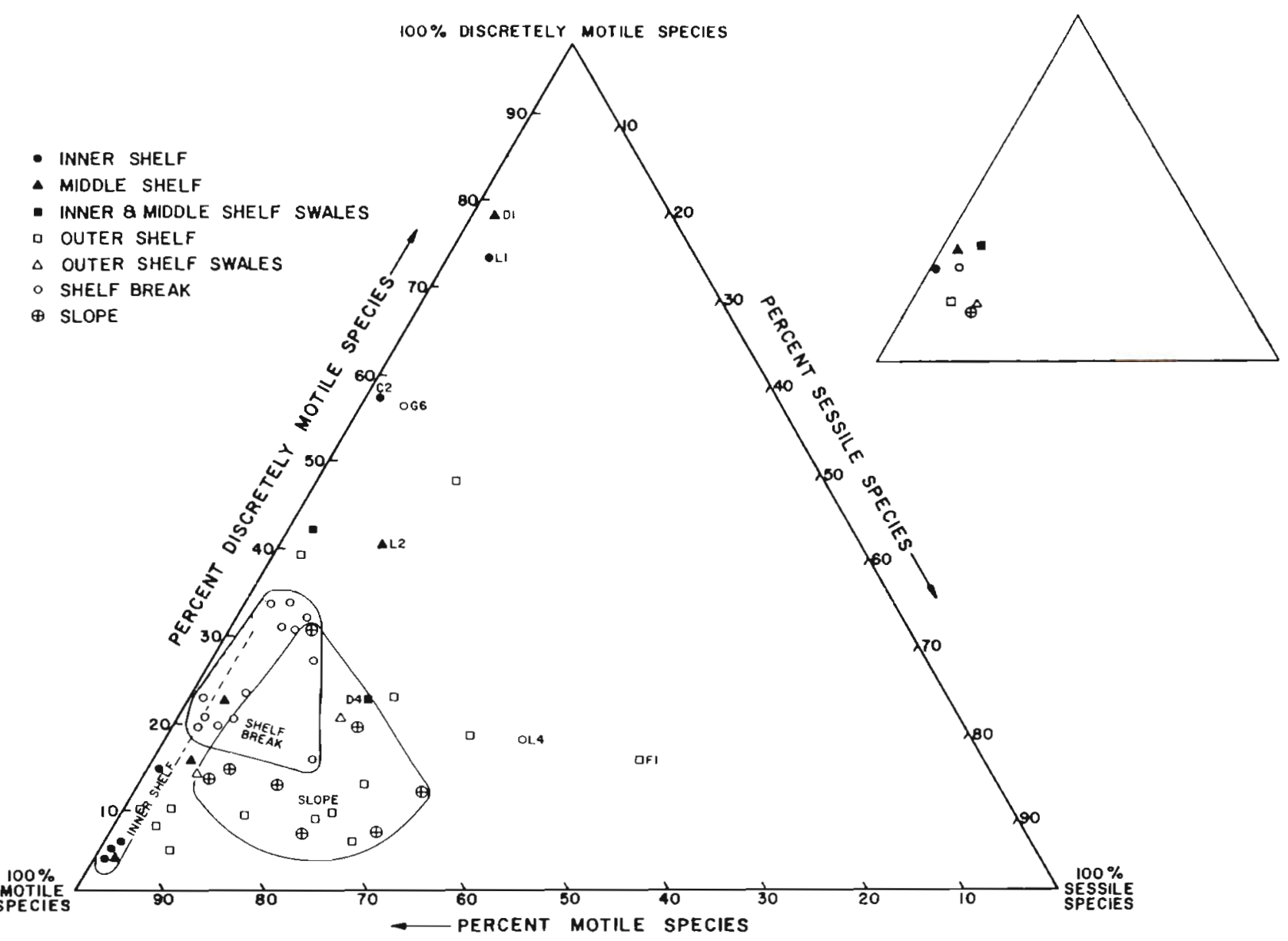

Fig. 4. Ternary diagram of broad scale sampling sites identified by habitat. Sites are distributed by percentage of the 3 components of polychaete motility: motile, discretely motile, and sessile. Mean values are plotted as centroids at right

a greater proportion of subsurface-deposit feeders than the inner and middle shelf, but fewer suspension feeders than the outer shelf.

Most of the stations were numerically dominated by motile species (Fig. 4). The inner shelf generally supported greater proportions of motile polychaetes than did deeper areas. The only inner shelf stations with less than $80 \%$ motile species were Stn L1, a habitat of physically dynamic fine or very fine sand, and Stn C2 located on a ridge flank with mediumcoarse sand. Both were densely populated with discretely motile species, primarily magelonids and spionids (e.g. Prionospio dayi and Spiophanes bombyx). Most middle shelf sites contained less than $2 \%$ sessile species, and were widely dispersed along the discretely-motile/motile axis. Outer shelf sites generally contained a greater proportion of sessile polychaetes than the inner or middle shelf. Stn F1, a medium-fine sand habitat on the shelf break, had a greater proportion of sessile polychaetes $(50 \%)$ than any other site. This resulted from the extensive populations of Chone infundibuliformis supported there. Most shelf break stations were inhabited by 20 to $35 \%$ discretely motile species. Exceptions to this were Stn L4, which was abundant in the sessile species C. infundibuliformis, and Stn G6, which was occupied by $58 \%$ discretely motile polychaetes (mostly onuphids and eunicids). Many slope stations were generally similar to outer shelf stations in proportion of the motility components, though the 2 depth zones did not share similar polychaete assemblages.

The depth zones were not well distinguished when characterized by morphological criteria. Some patterns were evident, however. Greater proportions of jawed polychaetes (Fig. 5) occurred on the inner shelf than occurred at other depth zones, though inner shelf Stns C2 and L1 were both dominated by tentaculate polychaetes (e.g. magelonicls and spionids). There was a trend toward more tentaculate species on the outer shelf than at shallower zones, though Stn L3 was distinguished from other shelf sites by abundance of soft proboscis polychaetes, especially orbiniids and paraonids.

Slope stations generally supported fewer jawed 
polychaetes than most other habitats. There were also fewer jawed species in the inner and middle shelf swales, though the polychaete fauna there was different from that of the continental slope.

\section{DISCUSSION AND CONCLUSIONS}

This study was based on gut-contents analyses of polychaete species collected in the Middle Atlantic Bight. The gut-contents analyses led to feeding biology classifications based on observations of ingested food. Such observations provided data on feeding by many polychaete species that had not been previously studied. Additionally, data on many species (e. g. dorvilleids, eunicids, goniadids, lumbrinerids) indicated a different feeding mode than was previously known.

It was demonstrated that the feeding biology of polychaetes in the Middle Atlantic Bight varied between habitats, and that patterns existed in the distribution of feeding biology parameters. Cross-shelf analyses indicated that carnivorous polychaetes were in greatest proportion in coarser sediments of the continental shelf, and that the proportion of carnivores decreased significantly with depth. These results confirmed observations by Boesch (1979a) that there is a trend toward carnivory in coarser sands of the Middle Atlantic Bight. Boesch's (1979a) conclusions were based on distribution of dominant species of benthic macrofauna. He mentioned 2 polychaete species in particular, Lumbrinerides acuta and Goniadella gracilis, which were dominant in much of the inner and middle shelf and in the coarse sediment habitats of the outer shelf. Because of Boesch's observations it was expected a priori that a positive relation existed between carnivorous polychaetes and coarse sediments. Also, Maurer \& Leathem (1981) found that the density of motile, jawed carnivorous polychaetes from Georges Bank increased significantly with sand and decreased with carbon during certain seasons. Carnivorous polychaetes of this study were in greatest proportion in the inner shelf $(53 \%$ of individuals collected) and middle shelf zones $(40 \%)$ and were least at the shelf break $(7 \%)$.

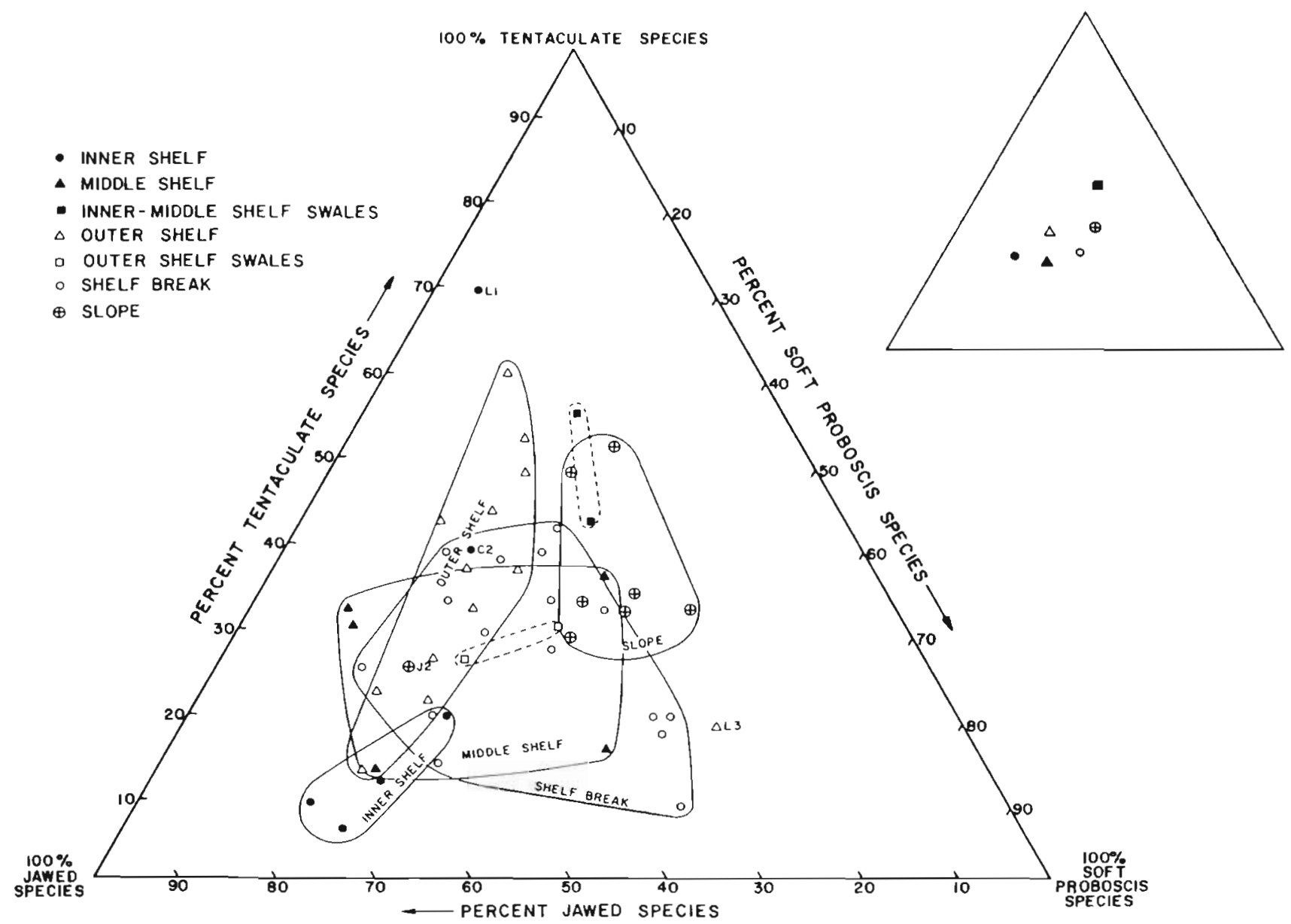

Fig. 5. Ternary diagram of broad scale sampling sites identified by habitat. Sites are distributed by percentage of the 3 primary components of polychaete morphology: jawed, tentaculate, and soft proboscis. Mean values are plotted as centroids at right 
The reason for the correlation of carnivorous polychaetes with coarse sand probably cannot be conclusively resolved without studies of live organisms. One might hypothesize that carnivorous polychaetes were abundant in coarse sediments because of the physical structure and dynamic characteristics of coarse sediments. Most carnivorous polychaetes collected in the study area were small, interstitial-feeding species (e.g. dorvilleids, phyllodocids, juvenile nephtyids), whose feeding and movement depended on size of the sediment interstices. Coarser sediments have greater pore space between sand grains which enhances movement of interstitial organisms such as the small peracarids and small polychaetes that were ingested by juvenile nephtyids. Greater pore space also enhances movement of the carnivores, and enhances oxygen penetration of the sediments (Fenchel 1970). In contrast, finer sediment habitats supported carnivorous polychaetes that fed primarily at the sediment-water interface. Limited pore space there probably precluded existence of most interstitial prey species.

Surface-deposit feeders numerically dominated most habitats, and were in greatest proportion in coarsesediment areas (i. e. most habitats except topographic depressions). Coarse sediment areas sometimes allowed intermittent surface detritus accumulation, but were periodically scoured of fine sediments by currents (Swift 1976). Therefore, substantial detritus was seldom buried in the sediments of most shelf habitats. Boesch (1979a) proposed that deposit feeders in such coarse-sediment habitats of the Middle Atlantic Bight were primarlily dependent on recently sedimented plankton detritus. In light of the dominance of coarse sediments of the study area by surfacedeposit feeders, this appears to be true. Maurer et al. (1982) reached a similar conclusion for polychaetes of the outer shelf off New Jersey.

If abundance of surface-deposit feeders in the Middle Atlantic Bight is related to recently sedimented food, then perhaps food is limiting, and we might expect surface-deposit feeders to dominate areas of greatest plankton production. Phytoplankton biomass and productivity in the Middle Atlantic Bight generally decreases from the inner to the outer shelf, then sharply increases at the shelf break (Walsh et al. 1978, Malone et al. 1979). The increase at the shelf break is believed by Malone et al. (1979) to be due to increased enrichment provided by a frontal system at the shelf break. Cross-shelf analysis by Gaston (1983) showed that abundance and proportion of surface-deposit feeding polychaetes in the Middle Atlantic Bight closely paralleled the pattern of phytoplankton production. Surface-deposit feeders were significantly more abundant and in greatest proportion on the inner shelf, decreased across the shelf, then increased at the shelf break.
Generally, subsurface-deposit feeders were less abundant in the study area than were surface-deposit feeders. The distribution of the subsurface-deposit feeders was probably affected by 2 primary criteria: (1) the presence of ample subsurface food resources; and (2) the adequate exchange of solutes between the sediments and the overlying water column. Because of the activities of the surface-deposit feeders, most sedimented nutrients in coarse-sediment habitats of the study area probably were ingested at the sediment surface. Fine-sediment habitats, such as topographic depressions, were more likely to provide the subsurface food resources necessary to support subsurfacedeposit feeders. Generally, topographic depressions act as sediment sinks that accumulate sediment and subsequently bury detritus (Swift 1976). It was not surprising, therefore, that the greatest proportion of subsurface-deposit feeders in the Middle Atlantic Bight was found in finer sediment habitats (i.e. swales).

The abundance of subsurface-deposit feeders in swales was also dependent on the second criterion: the adequate exchange of solutes between sediments and overlying water. Without this exchange, metabolites accumulate in the sediment and oxygen penetration is limited (Fenchel 1970). Recent investigations demonstrated that tube-dwelling macrobenthos (e.g. Aller 1978, Aller \& Yingst 1978, Brenchley 1979, Aller 1980, 1982) and surface- and subsurface-deposit feeders (e.g. Thayer 1979, Yingst \& Rhoads 1980, Hammond 1981) may have an indirect influence on the distribution of subsurface-feeding species by altering the geochemical characteristics of the sediments. Additionally, biogenic reworking of sediments by burrowers and tube irrigation by tube dwellers enhance the exchange of solutes between the water column and pore water (Rhoads et al. 1978, McCaffrey et al. 1980). Thus, presence of macrobenthic organisms may increase vertical penetration of oxygen to the sediments, increase transfer rate of nutrients into sediments, and eliminate metabolites from sediments. This effectively increases standing stocks of bacteria (Yingst \& Rhoads 1980, Yingst \& Aller 1982), other microorganisms, and microalgae which are recognized by most investigators (e. g. Kofoed 1975, Levinton et al. 1984, Phillips 1984) as the actual food of deposit feeders. Therefore, except where biogenic activity in sediments is extreme or where tube dwellers are so close as to abut, the presence of deposit feeders and most tubedwelling species improves habitat for subsurfacedeposit feeders. Topographic depressions of the Middle Atlantic continental shelf are occupied by rich assemblages of benthic organisms. These all may contribute to the exchange of solutes between sediments and the water column, ultimately enhancing the pre- 
sence of subsurface-deposit feeders in topographic lows.

Very few studies have used motility as a criterion for distinguishing patterns in species distributions. Jumars \& Fauchald (1977) proposed that sediment stability and flux of organic matter were the covariables most responsible for correlations of proportion of sessile polychaetes with depth. They provided an extensive discussion of the relationship between polychaetes and their environment, including influence of sediment mobility, foraging radius of species, and variations in nutritional influx. Cross-shelf analyses of this study indicated that proportion of sessile polychaetes was positively correlated with percent silt and clay and percent organic carbon. Although the bathymetric range of this study area limited adequate testing of some of Jumars \& Fauchald's (1977) hypotheses concerning the association of sessile species with foraging radius and sediment stability, the positive correlation of sessile polychaetes of the study area with organic carbon and silt and clay supports their contention that sessile polychaetes generally inhabit continental shelf habitats which are physically stable. Furthermore, the dominance of motile polychaetes in all cross-shelf depth zones (Fig. 2) of the Middle Atlantic Bight is probably indicative of the unstable nature of most habitats. The only exception to this generalization was that discretely motile polychaetes dominated some fine-sediment habitats of the inner and middle shelf off Virginia. Generally, however, surficial sediments of the study area were coarse, sand-sized particles (Freeland \& Swift 1978). Many investigators (e. g. Duane et al. 1972, Swift et al. 1972, Swift 1976) have characterized the Middle Atlantic Bight continental shelf as being covered by a surficial sand sheet that may be regulary redistributed. This sediment movement is greatest on the inner shelf, but may occasionally occur at all shelf depths (Butman et al. 1979). It is not surprising, therefore, that motile species dominated all depth zones. It is likely that domination by motile species also exists in other continental shelf areas covered by physically dynamic sediments, such as the South Atlantic Bight (Florida to North Carolina).

Feeding-morphology categories were less useful in distinguishing habitats in the study area than were feeding or motility categories. There were, however, some consistent, general patterns in the distribution of polychaetes based on morphology. Since most of the soft-proboscis polychaetes in the Middle Atlantic Bight were deposit feeders, I expected that soft-proboscis polychaetes would be most abundant in habitats of greatest accumulation of detritus (i.e. swales). This was tested using the Middle Atlantic outer-shelf ridge and swale habitats (Gaston 1983). Although soft-prob- oscis species did not numerically dominate any of the ridge field habitats, soft-proboscis polychaetes were in greatest proportion in deep and eroded outer shelf swales. These deepest areas were the ridge and swale habitats of greatest silt and clay content and greatest organic carbon content. Other feeding morphology components were here used to distinguish cross-shelf habitats. Tentaculate polychaetes were significantly more abundant in inner and middle shelf topographic depressions. Jawed polychaetes were generally associated with coarse-sediment habitats (e.g. ridges, terraces) and tentaculate polychaetes were associated with intermediate habitats (e.g. ridge flanks, shallow swales). The trend toward dominance of coarse sediments by jawed polychaetes was expected, since most jawed species on the outer shelf were motile carnivores. The functional advantage of jawed motile carnivores in coarse-grained sediments was discussed by Fauchald \& Jumars (1979). They proposed that jawed species are better adapted to ingesting variable prey sizes than nonjawed species. Furthermore, motility is adaptive for carnivory when food is scarce but not limiting.

\section{LITERATURE CITED}

Aller, R. C. (1978). The effects of animal-sediment interactions of geochemical processes near the sediment-water interface. In: Wiley, M., (ed.) Estuarine interactions. Academic Press, New York, p. 157-172

Aller, R. C. (1980). Relationships of tube-dwelling benthos with sediment and overlying water chemistry. In: Tenore, D. R., Coull, B. C. (ed.) Marine benthic dynamics. Univ. of South Carolina Press, Columbia, p. 285-308

Aller, R. C. (1982). The effects of macrobenthos on chemical properties of marine sediment and overlying water. Chapter 2. In: McCall, P. L., Tevesz, M. J. S. (ed.) Animalsediment relations. Plenum Publishing Corporation, New York, p. 53-102

Aller, R. C., Yingst, J. Y. (1978). Biogeochemistry of tubedwellings: a study of the sedentary polychaete Amphitrite ornata (Leidy). J. mar. Res. 36 (2): 201-254

Boesch, D. F. (1979a). Benthic ecological studies: macrobenthos. In: Middle Atlantic outer continental shelf environmental studies, Volume IIB. Chemical and biological benchmark studies. Prepared by the Virginia Institute of Marine Science, Gloucester Point, VA under Contract No. AA550-CT6-62 with the Bureau of Land Management, U.S. Department of Interior

Boesch, D. F. (1979b). Bottom sediments und sedimentary framework. In: Middle Atlantic outer continental shelf environmental studies, Volume IIB. Chemical and biological benchmark studies. Prepared by the Virginia Institute of Marine Science, Gloucester Point, VA under Contract No. AA550-CT6-62 with the Bureau of Land Management, U.S. Department of Interior

Brenchley, G. A. (1979). On the regulation of marine infaunal assemblages at the morphological level: a study of the interactions between sediment stabilizers, destabilizers, and their sedimentary environment. Ph. D. dissertation, Johns Hopkins University, Baltimore 
Butman, B., Noble, M., Folger, D. W. (1979). Long-term observations of bottom current and bottom sediment movement on the Mid-Atlantic continental shelf. J. geophys. Res. 84 (C3): 1187-1205

Dauer, D. M. (1983). Functional morphology and feeding behavior of Scolelepis squamata (Polychaeta: Spionidae). Mar. Biol. 77: 279-285

Dauer, D. M., Maybury, C. A., Ewing, R. M. (1981). Feeding behavior and general ecology of several spionid polychaetes from the Chesapeake Bay. J. exp. mar. biol. Ecol. 54: 21-38

Duane, D. B., Field, M. E., Meisburber, E. P., Swift, D. J., Williams, S. J. (1972). Linear shoals on the Atlantic inner continental shelf, Florida to Long Island. In: Swift, D. J. P., Duane, D. B., Pilkey, L. H. (ed.) Shelf sediment transport: process and pattern. Dowden, Hutchinson and Ross, Stroudsburg, p. 447-498

Fauchald, K., Jumars, P. A. (1979). The diet of worms: a study of polychaete feeding guilds. Oceanogr. mar. Biol. A. Rev. 17: $193-284$

Fenchel, T. (1970). Studies on the decomposition of organic detritus derived from the turtle grass Thalassia testudinum. Limnol. Oceanogr. 15 (1): 14-20

Freeland, G. L., Swift, D. J. P. (1978). Surficial sediments. MESA New York Bight Atlas Monograph 10, New York Sea Grant Institute, Albany, New York

Gaston, G. R. (1983). Benthic polychaeta of the Middle Atlantic Bight: feeding and distribution. Ph. D. dissertation, College of William and Mary, Williamsburg

Hammond, L. S. (1981). Analysis of grain size modification in biogenic carbonate sediments by deposit-feeding holothurians and echinoids (Echinodermata). Limnol. Oceanogr. 26: 898-906

Jumars, P. A., Fauchald K. (1977). Between-community contrasts in successful polychaete feeding strategies. In: Coull, B. (ed.) Ecology of marine benthos. University of South Carolina Press, Columbia, p. 1-20

Kofoed, L. N. (1975). The feeding biology of Hydrobia ventros (Montagu). 1. The assimilation of different components of the food. J. exp. mar. Biol. Ecol. 19: 233-241

Levinton, J. S., Bianchi, T. S., Stewart, S. (1984). What is the role of particulate organic matter in benthic invertebrate nutrition? Bull. mar. Sci. 35 (3): 270-282

Levin, L. A. (1980). Dispersion, feeding behavior and competition in two spionid polychaetes. J. mar. Res. 39 (1): 98-117

Malone, T. C., Esaias, W. E., Falkowski, P. (1979). Plankton dynamics and nutrient cycling. Part 1 . Water column processes. Chapter 9. In: Oxygen depletion and associated benthic mortalities in New York Bight, 1976/NOAA Professional Paper 11

Maurer, D., Leathem, W. (1981). Polychaete feeding guilds from Georges Bank, USA. Mar. Biol. 62: 161-171

Maurer, D., Leathem, W., Menzie, C. (1982). Macrobenthic invertebrates from the Middle Atlantic continental shelf Int. Revue ges. Hydrobiol. 67 (4): 491-515
McCaffrey, R. J., Myers, A. C., Davey, E., Morrison, G., Bender, M., Leudtke, N., Cullen, D., Froelich, P., Klinkhammer G. (1980). The relation between pore water chemistry and benthic fluxes of nutrients and manganese in Narragansett Bay, Rhode Island. Limnol. Oceanogr. 25: $31-44$

Phillips, N. W. (1984). Role of different microbes and substrates as potential suppliers of specific, essential nutrients to marine detritivores. Bull. mar. Sci. 35 (2): 283-298

Rhoads, D. C. (1974). Organism-sediment relations on the muddy sea floor. Oceanogr. mar. Biol. A. Rev. 12: 263-300

Rhoads, D. C., McCall, P. L., Yingst, J. Y. (1978). Disturbance and production on the estuarine seafloor. Am. Sci. 66 (4): $577-586$

Sokal, R. R., Rohlf, F. J. (1981). Biometry, 2nd edn. W. H. Freeman and Co., San Francisco

Swift, D. J. P. (1976). Continental shelf sedimentation. In: Stanley, D. J., Swift, D. J. P. (ed.) Marine sediment transport and environmental management. J. Wiley, New York p. $311-350$

Swift, D. J. P., Duane, D. B., McKinney, T. F. (1973). Ridge and swale topography of the Middle Atlantic Bight, North America: secular response to the Holocene hydraulic regime. Mar. Geol. 15: 227-247

Swift, D. J. P., Kofoed, J. W., Saulsbury, F. P., Sears, P. (1972). Holocene evolution of the shelf surface, central and southern Atlantic shelf of North America. In: Swift, D. J. P., Duane, D. B., Pilkey, O. H. (ed.) Shelf sediment transport: processes and patterns. Dowden, Hutchinson and Ross, Stroudsburg, p. 499-573

Taghon, G. L., Nowell, A. R. M., Jumars, P. A. (1980). Induction of suspension feeding in spionid polychaetes by high particulate fluxes. Science 210: 562-564

Thayer, C. W. (1979). Biological bulldozers and the evolution of marine benthic communities. Science 203: 458-461

Walsh, J. J., Whitledge, T. E., Barnevik, F. W., Wirick, C. D. Howe, S. O., Esaias, W. E., Scott, J. T. (1978). Wind events and food chain dynamics within the New York Bight. Limnol. Oceanogr. 23: 659-683

Whitlatch, R. B. (1981). Animal-sediment relationships in intertidal marine benthic habitats: some determinants of deposit-feeding species diversity. J. exp. mar. Biol. Ecol. 53: $31-45$

Woodin, S. A. (1978). Refuges, disturbance, and community structure: a marine soft bottom example. Ecology 59 (2): 274-284

Yingst, J. Y., Aller, R. C. (1982). The effect of the polychaete Heteromastus filiformis on bacteria in marine sediments. AGU-ASLO meeting. San Antonio, Texas, February $16-19,1982$

Yingst, J. Y., Rhoads, D. C. (1980). The role of bioturbation in the enhancement of bacterial growth rates in marine sediments. In: Tenore, K. R., Coull, B. C. (ed.) Marine benthic dynamics. Univ. of South Carolina Press, Columbia, $p$ $407-421$ 